\title{
REVIEW ON IMPLEMENTATION OF LEAN MANUFACTURING TOOLS
}

\author{
Siddharth Pimplapure \\ MTech Scholar, Department of Mechanical Engineering \\ BTIRT Sagar, Madhya Pradesh, India
}

\begin{abstract}
Lean Manufacturing is a beneficial and rapidly creating approach in the domain of competition. Lean Manufacturing is used for the interminable departure squanders in the assembling to improve the profitability and proficiency. The objective of this paper is to contemplate diverse lean thoughts under various lean procedures. This investigation helps with finding the status of lean assembling and its techniques for use. Most affiliations today are encountering a stage where there is a need to respond the rapidly changing customer needs. Also, lean assembling produces an operational and social atmosphere that is outstandingly useful for squander minimization. This paper presents a writing survey to clear the status from lean assembling and their techniques with help of assortment of significant papers.
\end{abstract}

Keywords-Lean Manufacturing, Productivity, Takt Time, NVA, Continuous Improvement

\section{INTRODUCTION}

Due to the growing work wage in non-industrial countries, the dress assembling has been moving from the significant salary created world to low wage non-industrial countries [1]. Piece of clothing undertakings in non-industrial countries are more engaged around sourcing of raw material and restricting transport cost than work efficiency because of the availability of modest work. Along these lines, work profitability is lower in agricultural countries than in the made ones. For example, work is very humble in Bangladesh anyway the profitability is poor among other non-industrial countries [22]. In fact, even today, organizations are getting the same or more volumes (orders), yet the amount of styles they need to manage has extended drastically. Regardless, these days as a result of little solicitation sums and complex plans, the garment business needs to convey different styles even inside a day; this prerequisites higher versatility in volume and style change over [23].

\section{PROBLEM DESCRIPTION}

The difficult issue individuals glanced in article of clothing industry is sewing/sewing; most of time powerlessness to meet movement time is a consequence of sewing/sewing. Sewing exercises (with respect to cutting and completing) needs high capacity similarly as quality work, considering inconvenience

\author{
Tarun Kumar Yadav \\ Asst. Prof., Department of Mechanical Engineering \\ BTIRT Sagar, Madhya Pradesh, India
}

related with fixing of things sewed with wrong conclusions. First thing, High WIP in traditional sort of bunch creation is the significant issue looked by ventures. Due to high WIP the throughput time similarly as revise is extraordinarily high.

Accordingly, the objective of this assessment is to find how we can use lean assembling to achieve the going with:

- To fulfill customer need on time by clearing out non worth added work from the cycle

- To restrict the work in cycle stock

- To make versatility of style changeover

- To lessen modify rate

- To make a pool of multi-talented administrators who can respond quickly for changing style

\section{LITERATURE REVIEW}

During II universal war, the monetary province of Japan was seriously squashed. As a result of this there was deficiency of resource achieving confining admittance to corporate money. At any rate Toyota expected to devise another framework for diminishes costs to help watching out. So they decided to convey a little cluster of things which would decrease inventories; it suggests they would require less cash to create a comparable thing.

Drew et al. (2004), presumed that short creation runs started by Toyota transformed into a preferred position instead of a weight, as it had the choice to respond significantly more rapidly to changes well known by quickly changing creation beginning with one model then onto the following. [5]

L. Wilson (2009), The well known significance of Lean Manufacturing and the Toyota Production System when in doubt includes the accompanying. [28]

1. It is a thorough game plan of methods which when combined licenses you to kills and decreases with the squanders. This will make the association less greasy, more adaptable and more responsive by diminishing waste.

2. Lean is the exact method to manage perceiving and clearing out waste through tireless improvement by streaming the thing or organization at the draw of your customer in mission for faultlessness [18].

Burton T. et al. (2003), the critical five principles of Lean are according to the accompanying: 


\section{International Journal of Engineering Applied Sciences and Technology, 2020 \\ Vol. 5, Issue 7, ISSN No. 2455-2143, Pages 237-241 \\ Published Online November 2020 in IJEAST (http://www.ijeast.com)}

Rule 1: Accurately show a motivator from customer perspective for the two things and organizations.

Rule 2: Identify the value move for things and organizations and dispose of non-regard adding waste along the value stream.

Rule 3: Make the thing and organizations stream without impedance over the value stream.

Rule 4: Authorize creation of things and organizations reliant on the draw by the customer.

Rule 5: Strive for faultlessness by consistently dispensing with layers of waste.[3]

Liker J. (2003), Concluded that in lean creation, when an administrator shuts down stuff to fix an issue, various exercises will moreover stop quickly in light of no stock making a crisis. So there is reliably a craving to move rapidly for everyone in progress to fix gives together to get the machine in working condition and to run the creation at the most punctual chance. [14]

David Magee (2007), state that different kinds of squanders in a cycle can be ordered in after characterizations. These squanders diminish creation adequacy, nature of work similarly as augmentation creation lead time.

Overproduction

Pausing

Pointless Transport

Over dealing with

Abundance Raw Material

Pointless Movement

Deformities

Unused Employee Creativity [16]

L. Wilson (2009), said that a cell is a mix of people, stuff and workstations facilitated in the solicitation for cycle to stream, to make all or part of a creation unit [28]. Following are the characteristics of successful cell fabricating practice.

1. Ought to have one-piece or little parcel of stream.

2. The hardware should address assessed and very sure for the cell exercises.

3. Is ordinarily arranged in a $\mathrm{C}$ or $\mathrm{U}$ shape so the moving toward crude materials and dynamic finished items are adequately checked.

4. Should incorporate comprehensively taught people groups inside the cell for versatility of activity.

5. All around, the cell is engineered in $\mathrm{C}$ or $\mathrm{U}$ shape and covers less space than the long mechanical creation frameworks. [28]

Gersten F. et al. (2002), presumed that Continuous improvement (CI) can be described as the orchestrated, composed and exact cycle of advancing, progressive and extensive contrast in existing practices highlighted improving association execution. [8]
Larson A. (2003), in his examination endless improvement is a ceaseless and unending cycle; it measures simply the achievements got from the use of one cycle over the current. So while picking the relentless improvement plan one should zero in on the domain which needs more thought and which upgrades our things. There are seven different kinds of unending improvement gadgets they can be portrayed as follows. The use of these instruments varies from case to case dependent upon the essential of the cycle to be checked. [13]

Shivanand H. K. (2006), in his exploration in the nick of time is an organized course of action of activities proposed to achieve high volume creation using the irrelevant inventories of crude materials, work in measure and finished items, Without a without a moment to spare is moreover established on the reasoning that nothing will be created until it is required. [23]

Roy R.N. (2005), presumed that evenhanded of JIT is the outright removal of waste in the assembling cycle. Despite the way that JIT framework is applied by and large to assembling atmosphere, the thoughts are not confined to this domain of business in a manner of speaking. The perspective of JIT is a reliable improvement that puts highlight on evasion rather than amendment, and solicitations a companywide base on quality. It relies upon conveying simply the significant units in the crucial sums at the essential time by adjusting creation rates accurately with market revenue. To lay it out simply, JIT suggests making what the market needs, when it needs, by using at any rate workplaces, stuff, materials, and HR. [21]

Bisen and Srivastava (2009), Concluded that machine breakdown is one of the critical cerebral agonies for people groups related to creation. The steady nature of the gear on the shop floor is huge since, in such a case that any of the machines is down the entire shop floor efficiency may be nil. The gadget that manages these unexpected breakdowns and gets up help similarly as creation workers to restrict these spontaneous breakdowns is called all out beneficial upkeep. All out Productive Maintenance (TPM) is a help program, which incorporates an as of late described thought for keeping up plants and gear. The goal of the TPM program is to extend creation, increase delegate soul and work satisfaction. [2]

Kumar (2008), said that in his exploration Kaizen is for little updates, yet finished reliably and remember all people for the affiliation. Kaizen requires no or little endeavor. The norm behind is that "a huge number of little improvements are more feasible in a hierarchical atmosphere than two or three overhauls of tremendous worth." This column is highlighted diminishing incidents in the workplace that impact our efficiencies. [12]

Karlsson and Ahlstrom (1996), reasoned that a bit of the waste decrease instruments fuse zero distortions, arrangement 


\section{International Journal of Engineering Applied Sciences and Technology, 2020 \\ Vol. 5, Issue 7, ISSN No. 2455-2143, Pages 237-241 \\ Published Online November 2020 in IJEAST (http://www.ijeast.com)}

time diminishing, and line adjusting. The target of zero defects is to ensure that things are without inadequacy right, through persistent improvement of the assembling cycle.

Yadav T. K. (2019), inferred that when Increase the creation or profitability by the organization, decrease the NVA and per item cost of the finished result, however it is difficult assignment. In his examination to less the mechanical production system and gathering time in medium size fabricating venture with the assistance of MOST. The final products are the plan of a board sequential construction system. This will guarantee that each workstation is working in a synchronized manner, neither speedier nor slower than various workstations. [4]

Heizer et al. (2000), Method study fixates on how a task can (should) be developed. Whether or not controlling a machine or making or amassing sections, how an endeavor is done has any sort of impact in execution, security, and quality. Using data from ergonomics and techniques assessment, strategies engineers are blamed for ensuring quality and sum standards are cultivated capably and safely. Strategies examination and related techniques are useful in office conditions similarly as in the plant. Techniques methodology are used to analyze the going with, Predetermined Time Standards segment manual work into minimal essential segments that as of now have set up occasions (considering gigantic instances of workers). To measure the ideal open door for a particular task, the time factors for each fundamental segment of that endeavor are added together. Developing a broad plan of Predetermined Time Standards would be prohibitively exorbitant for some irregular firm. Subsequently, different frameworks are financially open. The most broadly perceived predestined time standard is techniques time assessment (MTM), which is the aftereffect of the MTM association. [9]

Jain S. and Yadav T. K. (2017), study that review the current plant format of a Pulse Processing Mills. furthermore, to plan an improved plant format utilizing SLP (Systematic Layout Planning) to build its efficiency. Investigation of the current plant format was made by considering angles like progression of materials, action connections and space prerequisites. The examination serves to improve measures, dispense with item, material taking care of and measure deserts and to lessen process durations and quicken measures. [11]

Jain S. and Yadav T. K. (2017), research on the quantity of gear and apparatuses in Pulse processing are examined. Assess the proposed elective formats dependent on the Systematic Layout arranging design hypothesis (SLP) for expanded efficiency. The definite investigation of the plant format, for example, stream of material and action relationship outline and space relationship chart has been researched. The new plant format has been planned and contrasted and the current plant design. The SLP strategy indicated that new plant format essentially decline the distance of material stream starting with one stone roller then onto the next stone roller. [10]

Sharma (2009), inferred that Line Balancing is for the most part endeavored to restrict abnormality between machines or work force while meeting a vital yield from the line. The creation rate is appeared as cycle span to convey one unit of the thing; the ideal utilization of work power depends upon the reason of yield norms. The genuine yield of the individual may be not exactly equivalent to the yield principles. An occasion to work the framework, therefore, keeps fluctuating. It is, thusly, imperative to assemble certain activities to workstations to the tune of breaking point of cycle span at each work station. The mechanical creation framework needs to change so that there is least holding up of the line in view of different action time at each workstation. The sequencing is along these lines, not simply the part of men and machines to working activities, yet also the ideal utilization of workplaces by the most ideal changing of the consecutive development framework. [24]

Rother and Harris (2008), presumed that the Takt is German word for a development or beat, often associated with conductor's bludgeon. Takt time is a reference number that is used to help organize the speed of creation in a pacemaker cycle to the speed of arrangements. This can be characterized as under. Process duration is portrayed as how consistently a finished thing rises up out of our creation office. Process duration fuses a wide scope of concedes occurred while completing a work. So process duration can be dictated by the going with formula. [19][20]

Soni P. and Yadav T.K. (2018), this examination centers around a use of poka burden procedure on a cutting taking care of hardware of a liner cutting machine at a phone in liner producing organization. Probability of liner mouth misalignment to forestall the dismissal and increment the profitability. As indicated by the preferences which we found on the investigation we can without much of a stretch increment the creation by $10-20$ rates by utilizing this procedure. The poka burden is additionally causing us to diminishing the wastage rates. [27]

Soni P. and Yadav T. K. (2018), research in this examination the poka-burden strategy is managing the efficiency of the organization and with the flawlessness of the item which an organization is making. By past record we see that, the wastage rate is $11 \%$ for 1 roll and requiring 15 second to cut a solitary liner. Subsequent to introducing the poka burden strategy the wastage rate which we accomplished that is $4 \%$ and the cutting time is 6 second for a solitary liner. [26] 


\section{International Journal of Engineering Applied Sciences and Technology, 2020 \\ Vol. 5, Issue 7, ISSN No. 2455-2143, Pages 237-241 \\ Published Online November 2020 in IJEAST (http://www.ijeast.com)}

\section{PRESEARCH APPROACH}

The hidden development in this assessment is to proficiently examine and portray the recorded scenery of the lean assembling thought and its different apparatuses and procedures. It will by then gander at some most used lean assembling apparatuses and procedures. This will be followed by the examination of the current creation course of action of the case association for example the current creation formats, stock advancement structures, work adjusting techniques and other different components which should be improved for the headway of the current system.

\section{A. GARMENT MANUFACTURIGN PROCESS}

The mechanical office contains focus cutting division, 3 free sewing/sewing lines and focal finishing the way toward (pressing) region. Overall, administrators are liable for the nature of individual work, even after that there is quality check (review) around the completion of each fragment (division) so that there should not be any harmed parts moved beginning with one section then onto the following territory. The overall creation stream framework of the shop floor is showed up in Figure 1.

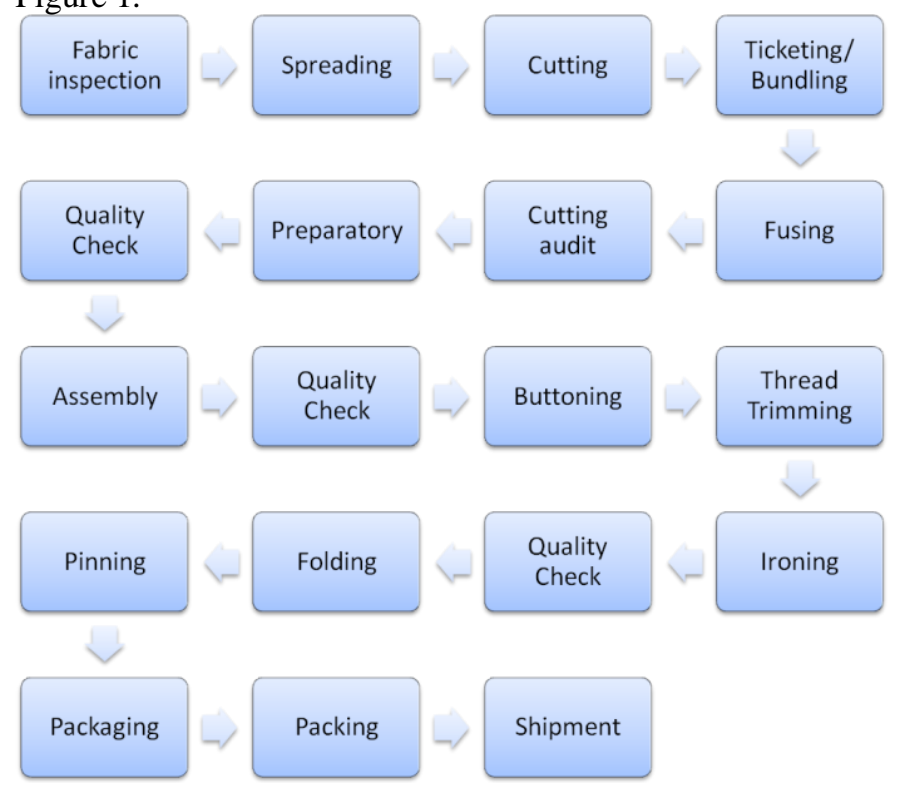

Fig.1. Garment production process flow chart (Naresh Paneru 2011)

Garment delivering measure includes plan of different advances. These methods are thoroughly parceled into two arrangements pre-creation and creation measure. The preproduction cycle includes arranging the planning of garments, plan arrangement, test making, creation configuration making, assessing and marker making. At the point when the example is supported for business creation, last marker is made for cutting. The creation cycle involves cutting, sewing/sewing (primer and get together) and finishing all these cycle are portrayed here.

\section{(A) Cutting Section \\ (B) Preparatory Section \\ (C) Assembly Section \\ (D) Finishing Section}

Style correspondence between different staffs and administrators is essential segment of garment assembling to restrict style related disarray during creation. Since the plan changes so as frequently as conceivable that there may be the need of creating new styles every day, so in the present condition if the shop floor people groups didn't get definite information for the garment being conveyed chances of slips up are high.

\section{B. EXISTING PRODUCTION LAYOUT}

In this design, the individual parts are made in fundamental regions and these parts are then moved physically to the gathering section. In the gathering section, these parts are amassed to shape a last garment. There is quality check close to the completion of each fragment to dodge imperfect parts to the accompanying stage. WIP development in fundamental region is made with the help of the long table close by machines, while work assists associated with each machine fills this need in the get together area.

There are different sorts of WIP development structures applied in garment creating undertakings. Some of them are customary, for example by streetcars or by hand pass on.

\section{CONCLUSION}

In this review paper, we have study the various kinds of examination paper identified with the lean assembling and their instruments utilized in the diverse association and the ventures to improve the profitability and creation of the item. As indicated by this examination I utilized the lean assembling and their apparatuses to improve the efficiency and lessen the imperfections in articles of clothing enterprises by applying the lean assembling instruments.

\section{REFERENCE}

[1] Bheda, R., Narag, A.S. and Singla, M.L. (2003) Apparel Manufacturing a Strategy for Productivity Improvement, Journal of Fashion Marketing and Management, Volume 7. No1, pp 12-22, MCB up limited. [available at: http://www.emeraldinsight.com/journals.htm?articleid=85 $\underline{8534}$ \&show=pdf] [viewed on: 04.10.2011].

[2] Bisen, V. and Srivastava, S. (2009). Production and Operation Management. Lucknow, India Global Media, p. 175.

[3] Burton, Terence T., and Boeder, Steven M. (2003). Lean Extended Enterprise: Moving Beyond the Four Walls to Value Stream Excellence. Boca Raton, FL, USA: J. Ross Publishing Inc. p. 122. [available at: 


\section{International Journal of Engineering Applied Sciences and Technology, 2020 \\ Vol. 5, Issue 7, ISSN No. 2455-2143, Pages 237-241 \\ Published Online November 2020 in IJEAST (http://www.ijeast.com)}

http://site.ebray.com/lib/oamk/Doc?id=10124747\&ppg=1 22] [viewed on 04.10.2011]

[4] Deshmukh M, Yadav T. K., Rajput S. (2019). Optimization and Implementation of Engine Assembly Line in Medium Size Manufacturing Processes International Journal of Innovative Science and Research Technology. Volume 4, Issue 1. ISSN No:-2456-2165, Pages 590-593.

[5] Drew, J., Blair, M. and Stefan, R. (2004). Journey to Lean: Making Operational Change Stick. Gordonsville, VA, USA: Palgrave Macmillan. p. 5-25.

[6] Feld, M.W., (2000). Lean Manufacturing: Tools, Techniques, and how to use them. Boca Raton, London: The St. Lucie Press.

[7] Gao L., Norton M. J. T., Zhang Z. and Kin-man (2009). To C. Potential Niche Markets for Luxury Fashion Goods in China. Journal of Fashion Marketing and Management Vol. 13 No. 4, p. 514-526.

[8] Gersten, F. (ed), and Riis, Jens O. (ed)., (2002). Continuous Improvement and Innovation. Bradford, GBR: Emerald Group Publishing Ltd. p. 41. [available at: http://site.ebrary.com/lib/oamk/Doc?id=10052730] [viewed on: 20.09.2011].

[9] Heizer, J., and Render, B. (2000), Principles of Operations Management 4th Edition. Pearson College Div. ISBN-10: 0130271470. p. 336-420.

[10] Jain S., Yadav T.K. (2017). SYSTEMATIC LAYOUT PLANNING: Improvement in the Layout Design of Pulse Processing Unit. International Journal of Engineering Applied Sciences and Technology. Vol. 2, Issue 9, ISSN No. 2455-2143, Pages 28-35

[11] Jain S., Yadav T.K. (2017). SYSTEMATIC LAYOUT PLANNING: A Review of Improvement in Approach to Pulse Processing Mills International Research Journal of Engineering and Technology (IRJET). e-ISSN: 2395 0056 , Volume: 04 Issue: 05. p-ISSN: 2395-0072. Pages 503-507.

[12] Kumar, S. A. (2008). Production and Operations Management. Daryaganj, Delhi, India: New Age International, p. 217-220.

[13] Larson, A. (2003). Demystifying Six Sigma: A CompanyWide Approach to Continuous Improvement. Saranac Lake, NY, USA: AMACOM Books. p. 46.

[14] Liker, J. (2003). Toyota Way. Blacklick, OH, USA: McGraw-Hill Professional Publishing, p. 28-33.

[15] Lucy Daly, M.B. and Towers, N. Lean or Agile: A Solution for Supply Chain Management in the Textile and Clothing Industry. International Journal of Operations \& Production Management Vol. 24 No. 2, 2004, p. 151-170.

[16] Magee, D. (2007). How Toyota Became \# 1 Leadership Lessons from the World's Greatest Car Company. New York, USA: Penguin Group. p. 67.
[17] Mid-America Manufacturing Technology Center, 'Lean Manufacturing Utilizes Multiple Tools to Help Companies Improve Performance Objectives, 'The Manufacturer's Edge. (winter 2000), p 1-2

[18] Nash, A. M., Poling, S. R., and Ward, S. (2006). Using Lean for Faster Six Sigma Results a Synchronized Approach. New York, USA: Productivity Press. p. 17.

[19] Rother, M. and Harris, R., (2008). Creating Continuous Flow an Action Guide for Managers, Engineers and Production Associates. One Cambridge Center, Cambridge USA: Lean Enterprise Institute. p. 13-1.

[20] Rother, M. and Shook, J. (1998). Learning to See: value stream mapping to create value and eliminate muda. MA USA: Lean Enterprise Institute.

[21] Roy, R. N. (2005). Modern Approach to Operations Management. Daryaganj, Delhi, India: New Age International. p. 170-174.

[22] Shahidul, M. I. and Syed Shazali, S. T.(2011) Dynamics of manufacturing Productivity: Lesson Learnt from Labor Intensive Industries. Journal of Manufacturing Technology Management Vol. 22 No. 5, 2011, p. 664678.

[23] Shahram, T. and Cristian, M. (2011) The Impact of Lean Operations on the Chinese Manufacturing Performance. Journal of Manufacturing Technology Management Vol. 22 No. 2, 2011, p. 223-240.

[24] Sharma, A. (2009). Operations Research. Mumbai, India: Global Media. p. 179.

[25] Shivanand, H.K., (2006). Flexible Manufacturing System. Daryaganj, Delhi, India: New Age International. p. 4-50.

[26] Soni P., Yadav T. K. (2018). STUDY ON "PRODUCTIVITY IMPROVEMENT BY USING POKA YOKE". International Journal of Engineering Applied Sciences and Technology, Vol. 3, Issue 6, ISSN No. 2455-2143, Pages 17 - 21

[27] Soni P., Yadav T. (2018). Review Paper on "Productivity Improvement by using Poka-Yoke". International Research Journal of Engineering and Technology (IRJET). Volume: 05 Issue: 12. e-ISSN: 2395-0056, pISSN: 2395-0072. Pages 761-763

[28] Wilson, L. (2009). How to Implement Lean Manufacturing. New York: McGraw-Hill Professional Publishing. p. 29- 214.

[29] Womack, J.P., Jones, D.T. and Ross, D. (1990). The Machine That Changed the World. Canada: Macmillan Publishing Company. 